\title{
ANALISIS PENGUNGKAPAN CORPORATE SOCIAL RESPONSIBILITY DALAM LAPORAN TAHUNAN TERHADAP
}

\section{ABNORMAL RETURN}

\author{
Nana Umdiana ${ }^{1 *}$, Kodriyah $^{2}$, Dien Sefty Framita ${ }^{3}$ \\ ${ }^{1)}$ Univesrsitas Serang Raya, Banten, nanaumdianaunsera@gmail.com, Indonesia \\ ${ }^{2)}$ Universitas Serang Raya, Banyen. kodriyahunsera@gmail.com, Indonesia \\ ${ }^{3)}$ Universitas Serang Raya, Bamten, Diensefty84@gmail.com, Indonesia
}

\section{ARTICLE INFO}

\section{Article history:}

Received 10 Maret 2021

Received in Revised 18 April 2021

Accepted 23 April 2021

Keywords:

Corporate Social

Responsibility (CSR),

Abnormal Return

ABSTRACT

\begin{abstract}
The aim of the study was to analyze the effect of disclosure of Corporate Social Responsibility (CSR) in the Annual Report on Abnormal Return in manufacturing companies with the food and beverage sub-sector. The population in this study is manufacturing companies with food and beverage sub-sectors listed on the Indonesia Stock Exchange in 2014-2017. The method of selecting this research sample based on purposive sampling obtained 10 companies during the study period. Testing is done using simple linear regression. The results of the study show that the disclosure of Corporate Social Responsibility (CSR) in the Annual report affects the Abnormal Return. This proves that information about Corporate Social Responsibility (CSR) can be used as a consideration by investors for investment decision making.
\end{abstract}

Tujuan dari penelitian ini adalah untuk menganalisis pengaruh pengungkapan Corporate Social Responsibility (CSR) dalam Annual Report terhadap Abnormal Return pada perusahaan manufaktur sub sektor makanan dan minuman. Populasi dalam penelitian ini adalah perusahaan manufaktur dengan subsektor makanan dan minuman yang terdaftar di Bursa Efek Indonesia tahun 2014-2017. Metode pemilihan sampel penelitian ini berdasarkan purposive sampling diperoleh 10 perusahaan selama periode penelitian. Pengujian dilakukan dengan menggunakan regresi linier sederhana. Hasil penelitian menunjukkan bahwa pengungkapan Corporate Social Responsibility (CSR) dalam Laporan Tahunan berpengaruh terhadap Abnormal Return. Hal ini membuktikan bahwa informasi mengenai Corporate Social Responsibility (CSR) dapat digunakan sebagai bahan pertimbangan investor dalam pengambilan keputusan investasi

\section{AKUISISI : Jurnal Akuntansi}

Website : http://www.fe.ummetro.ac.id/ejournal/index.php/JA

This is an open access article distributed under the terms of the Creative Commons Attribution 4.0 International License, which permits unrestricted use, distribution, and reproduction in any medium, provided the original work is properly cited.

\footnotetext{
* Corresponding author. Tel.: +0-000-000-0000; fax: +0-000-000-0000. E-mail address: nanaumdianaunsera@gmail.com, Indonesia Peer review under responsibility of Akuisisi : Accounting Journal. 2477-2984. http://dx.doi.org/10.24217
} 


\section{PENDAHULUAN}

Pasar modal mempunyai fungsi sebagai penyedia fasilitas atau tempat bertemunya dua kepentingan yang berbeda yaitu pihak yang memiliki dana (investor) dan pihak yang membutuhkan dana (issuer). Dengan adanya pasar modal ini pihak yang memiliki dana dapat menginvestasikan dana tersebut dengan harapan memperoleh pengembalian (return) sesuai dengan karakteristik investasi yang mereka pilih sedangkan pihak issuer (dalam hal ini perusahaan) dapat menggunakan dana tersebut untuk kepentingan perusahaan tanpa harus menunggu dana yang tersedia dari operasi perusahaan. Ada berbagai macam sumber yang digunakan oleh investor dalam mempertimbangkan keputusannya. Salah satunya informasi mengenai Corporate Social Responsibility (CSR) yang dilakukan oleh perusahaan. Kesadaran masyarakat terhadap pelaporan CSR perusahaan telah mempengaruhi keputusan investasi.

Pelaporan mengenai pelaksanaan tanggung jawab sosial dan lingkungan Perseroan ini telah diwajibkan pula pada pasal 66 ayat 2 Undang No.40 Tahun 2007. Implementasi pelaksanaan tanggung jawab berkelanjutan di Indonesia didukung oleh sejumlah aturan seperti Undang-Undang No 32 Tahun 2009 tentang Perlindungan dan Pengelolaan Lingkungan Hidup (PPLH) yang merupakan hasil revisi dari Undang-Undang No 23 Tahun 1997 tentang Pengelolaan Lingkungan Hidup. Undang-Undang No 32 Tahun 2009 tentang PPLH tersebut juga menjelaskan mengenai sanksi yang dikenakan. Pelaporan itu sendiri memiliki tiga fokus pengungkapan menurut Global Reporting Intiative (GRI), yaitu kinerja ekonomi, lingkungan, dan sosial. Sedangkan kinerja sosial itu dikategorikan lebih lanjut menjadi tenaga kerja, hak asasi manusia, masyarakat, dan tanggung jawab terhadap produk. Walaupun telah diatur oleh Pemerintah dalam Undang-Undang, namun tata cara mengenai pelaksanaan CSR tidak dijelaskan secara lebih spesifik. Undang-Undang tidak menjelaskan secara rinci bagaimana CSR dilakukan dan dilaporankan dalam laporan tahunan, sehingga pelaksanaannya perusahaan terkesan hanya untuk memenuhi peraturan.

Investor dan konsumen lebih menyukai perusahaan yang memiliki kepedulian dan tanggung jawab terhadap lingkungan. Dengan adanya konsep pembangunan yang berkelanjutan ini, maka perusahaan tidak hanya dihadapkan pada tanggung jawab yang berpedoman pada single bottom line, yaitu nilai perusahaan yang tercermin dalam kondisi keuangannya saja. Tapi tanggung jawab perusahaan harus berpedoman pada triple bottom lines, yaitu people, planet, profit. Perusahaan dengan tingkat pengungkapan informasi CSR yang rendah diprediksi akan menghadapi future earning dengan prospek usaha yang besar mendatang terlihat tidak pasti. Kondisi keuangan saja tidak cukup menjamin nilai perusahaan tumbuh secara berkesinambungan, jadi investor juga akan menilai dan melihat kinerja perusahaan dari aspek lingkungan dan sosial perusahaan tersebut. 
Pasar efisien di uji dengan melihat return tidak normal atau abnormal return yang terjadi. Pasar dapat dikategorikan tidak efisien jika salah satu atau beberapa pelaku pasar berhasil menikmati return tidak normal dalam kurun waktu yang cukup lama (Hartono, 2009). Pada umumnya pemilik dana atau investor mengharapkan return yang normal dan proposional sesuai dengan dana yang dikorbankan untuk investasi tersebut. Namun bagi investor yang melek akan peluang (sophisticated) bisa memperoleh return tidak normal. Return ini disebut abnormal return, yang peroleh dari selisih antara return yang sesungguhnya terjadi (actual return) dengan return yang diharapkan oleh investor (expected return). Abnormal return akan positif jika return yang diperoleh lebih besar dari return yang diperhitungkan. Sedangkan abnormal return akan negatif jika return yang diperoleh lebih kecil dari return yang dihitungkan. (Hartono, 2009).

Abnormal return merupakan indikator perusahaan untuk melihat keadaan pasar (Jogiyanto 2009:124). Abnormal return terjadi ketika actual return yang didapatkan perusahaan melebihi return yang diprediksikan perusahaan. Peningkatan dari actual return (return yang telah terjadi) ini disebabkan oleh adanya informasi yang menarik investor sehingga mampu meningkatkan reaksi pasar. Informasi tambahan ini salah satunya adalah pengungkapan CSR dalam laporan tahunan. Apabila informasi CSR merupakan informasi yang digunakan dalam pertimbangan investor, maka hal ini menyebabkan kenaikan demand akan saham yang diikuti dengan kenaikan harga saham perusahaan. Kenaikan harga saham yang melebihi return yang diekspetasikan oleh investor yang akhirnya menyebabkan abnormal return dalam perusahaan. Sehingga dapat dikatakan bahwa informasi CSR dapat memberikan nilai tambah bagi investor dan menyebabkan abnormal return.

Semakin tinggi penggungkapan CSR yang dilakukan oleh perusahaan maka semakin tinggi abnormal return, begitu pula sebaliknya semakin rendah pengungkapan CSR yang dilakukan oleh perusahaan maka semakin rendah pula abnormal return. Hal ini dikarenakan pengungkapan tanggung jawab sosial perusahaan dapat menimbulkan image yang baik atau memiliki reputasi yang baik di mata stakeholder. Hal ini membuat investor dapat menilai bahwa perusahaan mempunyai kinerja yang baik sehingga mendorong investor untuk menginvestasikan modalnya pada perusahaan yang memiliki kinerja yang baik. Perusahaan yang mempunyai tingkat pengungkapan Corporate Social Responsibility (CSR) yang tinggi akan memberikan tingkat kepercayaan investor terhadap perusahaan tersebut. Hal ini di sebabkan karena investor semakin menyadari bahwa perusahaan tidak bisa hanya menghasilkan laba yang besar tanpa memberikan kontribusi yang lebih bagi masyarakat sekitarnya. Hal ini akan membuktikan bahwa perusahaan tidak hanya mengejar profit semata lagi tetapi sudah meperhatikan lingkungan dan masyarakat dengan menjalankan prinsip triple bottom line sehingga membuat image positif bagi perusahaan. Selain itu hal ini juga membuat semakin banyak investor yang berinvestasi pada perusahaan tersebut maka kenaikan pembelian saham perusahaan akan 
meningkatkan sehingga kenaikan harga saham yang melebihi return yang diekspektasi oleh investor sehingga pada akhirnya informasi CSR merupakan informasi yang memberikan nilai tambah bagi investor dan menyebabkan abnormal return.

Penelitian ini bertujuan untuk menguji pengaruh pengungkapan Corporate Social Responsibility (CSR) terhadap abnormal return. Hartono, (2009) menyatakan suatu informasi yang dipublikasikan sebagai suatu informasi akan memberikan tanda bagi investor dalam mempertimbangkan pengambilan keputusan investasi. Jika informasi yang terkandung dalam pengumuman tersebut bernilai positif, maka harapan pasar akan beraksi pada saat pengumuman tersebut diterima oleh pasar. Pengungkapan oleh perusahaan sesuai dengan teori stakeholder yang menyebutkan bahwa perusahaan tidak hanya entitas yang beroperasi untuk kepentingan sendiri, tapi harus memberikan dampak positif dan berguna kepada seluruh stakeholdernya (Ghozali dan Chairi, 2007). Dengan demikian keberadaan suatu perusahaan sangat dipengaruhi oleh dukungan yang diberikan stakeholders kepada perusahaan tersebut. Penelitian yang dilakukan oleh Cheng dan Christiawan (2011) memberikan hasil bahwa pengungkapan CSR berpengaruh positif signifikan terhadap abnormal return yang mencerminkan bahwa informasi pengungkapan CSR menjadi salah satu bahan pertimbangan investor dalam pengambilan keputusan investasi.

\section{TINJAUAN PUSTAKA}

\section{Pengungkapan Corporate Social Responsibility (CSR)}

World Business Council for Sustainable Development mendefinisikan CSR adalah suatu komitmen berkesinambungan oleh dunia usaha atau dunia industri untuk berlaku secara etis dan memberikan sumbangsih kepada perkembangan ekonomi dari masyarakat sekitar ataupun masyarakat secara luas, diiringi dengan meningkatnya kesejahteraan taraf hidup karyawan beserta seluruh keluarganya. Sedangkan, menurut ISO 26000, CSR adalah Tanggung jawab sebuah organisasi kepada masyarakat sekitar lingkungan akibat adanya keputusan atas kegiatan yang dilakukan organisasi tersebut yang diwujudkan dalam bentuk perilaku yang transparan dan etis sesuai dengan pembangunan berkesinambungan dan kesejahteraan masyarakat; mempertimbangkan keinginan stakeholder, sesuai dengan hukum yang ditetapkan dan aturan-aturan perilaku internasional; serta terintegrasi dengan kepentingan organisasi secara keseluruhan. Orientasi perusahaan selain terhadap laba, perusahaan juga memiliki tanggungjawab terhadap permasalahan sosial yang diakibatkan oleh kegiatan operasional perusahaan.

Manfaat yang didapat dengan adanya kegiatan CSR antara lain: meningkatkan jumlah pendapatan dan market share, meningkatkan citra perusahaan, memperkuat brand positioning, 
menurunkan biaya operasi, dan menjadi daya tarik perusahaan untuk menarik investor dan analisis keuangan. Dengan melakukan tanggung jawab sosial, perusahaan ditekankan tidak hanya berorientasi kepada keuntungan jangka pendek, tetapi juga ikut serta berkontribusi terhadap peningkatan kesejahteraan dan peningkatan taraf hidup masyarakat serta lingkungan sekitar dalam jangka panjang. Pelaksanakan CSR secara berkelanjutan dalam jangka panjang dapat menimbulkan rasa keberterimaan masyarakat sekitar dengan adanya perusahaan.

Pengungkapan CSR menjadi bagian dari akuntansi pertanggung jawaban sosial yang berisi informasi sosial yang ditujukan kepada stakeholder, pengungkapan informasi CSR dalam laporan tahunan menjadi salah satu upaya perusahaan untuk mempertahankan, membangun, dan melegitimasi sumbangsih perusahaan dari segi ekonomis dan politis. Selain itu juga, akuntansi pertanggungjawaban sosial mampu menyediakan informasi tentang kontribusi organisasi baik positif maupun negatif terhadap peningkatan taraf dan kualitas hidup masyarakat dan lingkungannya.

\section{Abnormal Return}

Jogianto Hartono (2013), Abnormal Return atau Acess Return merupakan kelebihan dari return yang sesungguhnya dengan return normal, return normal merupakan return ekspetasian (return yang diharapkan investor). Abnormal return merupakan indikator perusahaan untuk melihat keadaan pasar (Jogiyanto 2009:124). Abnormal return terjadi ketika actual return yang didapatkan perusahaan melebihi return yang diprediksikan perusahaan. Peningkatan dari actual return ini disebabkan oleh adanya informasi yang menarik investor sehingga mampu meningkatkan reaksi pasar.

\section{METODELOGI}

Metode Penelitian yang digunakan dalam penelitian ini adalah penelitian asosiatif tipe kausal. Dalam penelitian, penulis mengambil populasi perusahaan manufaktur sub sektor makanan dan minuman yang terdaftar di BEI periode 2014-2017 sebanyak 15 perusahaan. Teknik pengambilan sampel bedasarkan kriteria tertentu sesuai dengan tujuan penelitian yang dianggap mewakili penelitian.

\section{HASIL PENELITIAN DAN PEMBAHASAN}

Tabel 1

Hasil Pengujian

\begin{tabular}{lccc}
\hline \multicolumn{1}{c}{ Model } & Koefisien & T & Sig \\
\hline $\begin{array}{l}\text { Constant } \\
\text { Pengungkapan }\end{array}$ & 0,503 & 2,662 & 0,011 \\
$\begin{array}{l}\text { Corporate Social } \\
\text { Responsibility }\end{array}$ & 2,189 & 2,273 & 0,029 \\
\hline
\end{tabular}


Berdasarkan hasil pengujian pada table 1 bahwa Pengungkapan CSR berpengaruh terhadap Abnormal Return hal ini dapat menunjukkan bahwa Pengungkapan Corporate social responsibility dapat meningkatkan Abnormal Return. Hal ini dapat diartikan bahwa informasi Pengungkapan CSR yang dilakukan perusahaan dalam laporan tahunan selain dapat memperkuat citra perusahaan di mata stakeholder juga merupakan salah satu informasi yang menjadi bahan pertimbangan yang diperhatikan investor maupun calon investor dalam memilih tempat investasi dan semakin tinggi penggungkapan CSR yang dilakukan oleh perusahaan maka semakin tinggi abnormal return, begitu pula sebaliknya semakin rendah pengungkapan CSR yang dilakukan oleh perusahaan maka semakin rendah pula abnormal return. Hal ini akan membuktikan bahwa perusahaan tidak hanya mengejar profit semata lagi tetapi sudah meperhatikan lingkungan dan masyarakat dengan menjalankan prinsip triple bottom line (ekonomi, lingkungan dan sosial) sehingga membuat image positif bagi perusahaan.

Hasil penelitian ini mendukung hasil penelitian yang telah dilakukan oleh Rita dkk 2014 yang membuktikan bahwa pengungkapan corporate social responsibility berpengaruh signifikan terhadap Abnormal Return. Namun tidak sejalan dengan hasil penelitian Kastutisari dan Dewi tahun 2012 yang menyatakan bahwa pengungkapan corporate social responsibility tidak berpengaruh terhadap Abnormal Return. Ia juga menyatakan bahwa investor dan perusahaan masih memiliki persepsi rendah tentang CSR. Pengungkapan CSR tidak menyebabkan reaksi investor, sehingga tidak mempengaruhi abnormal return. Implikasi dari penelitian ini adalah bahwa investor kurang peduli dengan tanggung jawab sosial perusahaan dalam mengambil keputusan untuk berinvestasi.

\section{KESIMPULAN, KETERBATASAN DAN SARAN}

\section{Kesimpualan}

Dari penelitian yang dilakukan terhadap perusahaan manufaktur subsektor makanan dan minuman tahun 2014 sampai dengan 2017 diketahui Pengungkapan CSR yang diukur dengan indikator kinerja ekonomi, lingkungan, praktek tenaga kerja, hak asasi manusia, sosial, dan kinerja produk pada perusahaan manufaktur berpengaruh signifikan terhadap abnormal return. Hal ini menunjukkan bahwa semakin tinggi pengungkapan corporate social responsibility dapat meningkatkan abnormal return. Dengan demikian dapat membuktikan bahwa investor mengapresiasi item pengungkapan CSR

yang diungkapkan dalam laporan tahunan maupun sustainability report dalam pengambilan keputusan berinvestasi. 


\section{Keterbatasan}

1. Keterbatasan ditemukan dalam mencari pengungkapan tanggung jawab sosial perusahaan pada laporan tahunan. Karena rata-rata perusahaan dalam pengungkapan CSR belum sepenuhnya sesuai berdasarkan pada Global reporting Initiative (GRI).

2. Data yang digunakan dalam penelitian ini sebagian besar berupa laporan keuangan dan annual report perusahaan, oleh karena itu kemungkinan terdapat pengungkapan CSR melalui laporan lain yaitu sustainability report.

3. Periode penelitian ini terbatas, hanya pada periode 2014-2017, Jumlah sampel yang terbatas, dan hanya menggunakan satu variabel independen yaitu pengungkapan Corporate Social Responsibility sehingga hasil kesimpulan ini kurang dapat digeneralisasikan untuk periodeperiode yang lain.

4. Data yang digunakan untuk mengukur pengungkapan corporate social responsibility sebagian besar adalah merupakan data laporan tahunan perusahaan, sehingga tidak semua item di dalam daftar pengungkapan sosial diungkapkan secara jelas sebagaimana di dalam laporan keberlanjutan (sustainability report)

5. Penelitian ini membatasi observasinya hanya pada perusahaan manufaktur saja. Hal ini mengacu pada UU PT No. 40 Tahun 2007 yang menyatakan bahwa perusahaan pada sektor ini dinilai akan lebih banyak mengungkapkan informasi sosialnya.

\section{Saran}

1. Disarankan kepada perusahaan untuk meningkatkan pelaporan CSR yang selama ini dilakukan guna dapat meningkatkan abnormal return untuk menarik investor menanamkan saham di masa yang akan datang

2. Penelitian ini melakukan pengukuran pengungkapan corporate social responsibility dan abnormal return terhadap perusahaan manufaktur dengan subsektor makanan dan minuman Pada Bursa Efek Indonesia, untuk penelitian yang akan datang dapat dilakukan pada perusahaan non manufaktur jenis lainnya seperti perusahaan perbankan, perusahaan telekomunikasi, perusahaan agribisnis dan lain-lain.

3. Untuk penelitian selanjutnya, disarankan untuk memperbanyak jumlah sampel dan memperpanjang periode penelitian dan menambah variabel independen yang dapat 
mempengaruhi abnormal return seperti : koefisien respons laba (ERC), ukuran perusahaan, struktur modal perusahaan, leverage, dan pertumbuhan laba.

\section{DAFTAR PUSTAKA}

Arsita, Mirna. (2015) "Pengaruh Pengungkapan Corporate Social Responsibility Dan Informasi Keuangan Terhadap Abnormal Return. Jurnal Ilmu \& Riset Akuntansi Vol. 4 No. 6 1-13

Budi, Ega. (2013) "Corporate Social Responsibility Disclosure, Karakteristik Perusahaan dan pengaruhnya terhadap Earnings Response Coefficient, jurnal telaah dan riset akuntansi. 1-11

Bandi dan Hartono J., (1999), “ Perilaku Reaksi Harga dan Volume Perdagangan Saham terhadap Pengumuman Deviden”, Simposium Nasional Akuntansi II, Universitas Brawijaya.

Cheng, M., dan YJ. Christiawan., (2011) "Pengaruh Pengungkapan Corporate Social Responsibilty terhadap Abnormal Return", Jurnal Akuntansi dan Keuangan, Vol. 13, No. 01, hal 24-26, Mei 2011.

Christina, dan Yeterina Widi Nugrahanti. (2015) "Pengaruh Pengungkapan Corporate Social Responsibility Terhadap Reaksi Pasar" Jurnal Akuntansi Keuangan Dan Perbankan, November 2015, Vol. 4 No. 2 1-12

Ghozali, I. dan Chariri A., (2007), “Teori Akuntansi”, Badan Penerbit Universitas Diponegoro, Semarang.

Hari, Indra. (2013) "Pengaruh Sustainability Reporting Terhadap Abnormal Return Saham Pada Badan Usaha Sektor Pertambangan", Jurnal Ilmiah Mahasiswa Universitas Surabaya Vol.2 No.2 1-12

Hartono, Jogiyanto. (2009). Teori Portofolio dan Analisis Investasi. Edisi keenam. Yogyakarta: BPFE-Yogyakarta

Nurul, Savitri. (2012) "Pengaruh Pengungkapan Corporate Social Responsibility Terhadap Abnormal Return", Jurnal STIE Perbanas Surabaya 1-20

Rita, Muhammad Arfan dan dan M. Shabri. (2014) "Pengaruh Laba, Pengungkapan Corporate Social Responsibiity, Dan Profitabilitas Terhadap Abnormal Return Saham (Studi Empiris Pada Perusahaan Manufaktur Di Bursa Efek Indonesia), Jurnal Accounting,Volume 3, No. 1, Februari 2014 1-14

Sayekti, Y., dan KS. Wondabio. (2007), "Peng aruh CSR Disclousure terhadap Earning Response Coefficient", Simposium Nasional Akuntansi X, Unhas Makassar

Sugiyono. (2015). Metode Penelitian Kuantitatif, Kualitatif, dan R\&D. Bandung: CV. Alfabeta 